\title{
Phytochemical and Pharmacological Study of the Eysenhardtia Genus
}

\author{
Abraham Garcia-Campoy ${ }^{1}$ (D) Efrén Garcia ${ }^{2}$ and Alethia Muñiz-Ramirez ${ }^{3, *} * \mathbb{C}$ \\ 1 Laboratorio de Investigación de Productos Naturales, Escuela Superior de Ingeniería Química e Industrias \\ extractivas Instituto Politécnico Nacional, Av. Instituto Politécnico Nacional S/N, Unidad Profesional Adolfo \\ López Mateos, Ciudad de Mexico CP 07708, Mexico; abrahamhgc27@hotmail.com \\ 2 Laboratorio de Química Supramolecular y Nanociencias, Instituto Politécnico Nacional, Acueducto S/N, \\ Barrio la laguna Ticomán, Ciudad de Mexico CP 07340, Mexico; efren1003@yahoo.com.mx \\ 3 CONACYT-IPICYT/CIIDZA, Camino a la Presa de San José 2055, Col. Lomas 4 Sección, \\ San Luis Potosí S.L.P CP 78216, Mexico \\ * Correspondence: alethia.muniz@ipicyt.edu.mx
}

Received: 29 July 2020; Accepted: 18 August 2020; Published: 31 August 2020

\begin{abstract}
The participation of natural products in health care has been remarkable, and today they continue to play a key role in the discovery and development of new treatments. Phytochemical studies together with pharmacological tests have managed to integrate bioactive agents as an alternative solution to reduce or regulate the problems caused by diseases. The Eysenhardtia genus is a family of plants that are rich in secondary metabolites, which have shown potential activity in the control and mitigation of urinary disorders, diabetes, oxidative stress, protein glycosylation, microbial infections, inflammation, pain or discomfort, muscle contractions, cytotoxicity, or as a cellular or neuronal signaling modulator. These conditions generally appear in comorbid diseases, which motivated the bibliographic review associated with the plant. This document presents the beneficial actions produced by Eysenhardtia extracts and/or bioactives to inhibit, control, or reduce the complications or discomfort of degenerative diseases and thus generate new therapeutic alternatives.
\end{abstract}

Keywords: Eysenhardtia; phytochemical; pharmacological

\section{Introduction}

The relationship between humanity and medicinal plants goes back to ancient times. The oldest records found correspond to the Sumerians, approximately 5000 years ago [1]. The growth and development of civilizations have been closely linked to the use and exploitation of the healing properties of medicinal plants [2]. The process of recognition and use of herbalism in the preparation of remedies, infusions, or concoctions for the treatment of disease has been carried out by trial and error [3]. There are countries with a long tradition of using herbal medicine such as China, India, Japan, Pakistan, and Mexico. Ethnopharmacological studies have contributed to the amplification of knowledge and the discovery of new drugs or effective bioactive compounds for the control of diseases [4].

Mexico has a history of using ethnomedicine, whose origins go back to pre-Hispanic cultures where archaeological findings have shown its anthropological influence and impact on Mexican culture [5]. One of the plants with antecedents is Eysenhardtia polystachya (EP), dating back to the era of New Spain where Nicolas B. Monardes (1565) relates the use of a tree to treat kidney and urinary diseases; he describes that they drank a blue-colored infusion which was obtained by placing thin slices of a wood (bark) into water for a period of time [6]. Furthermore, in the Florentine Codex, Fray Bernardino de Sahagún refers to the use of "Coatli" for fever or retention of urine [7]. In the following centuries (XVI and XVII), it was taken to Europe where it was known as Lignum 
nephriticum $[8,9]$. Later, it continued to be consumed in a traditional way by Mexicans for the control of urinary, contraceptive [10], antidiarrheal, and antiseptic disorders, as well as for the control of diabetes [11,12].

In recent decades, the Eysenhardtia genus has attracted attention due to its medicinal properties. This triggered a series of phytochemical and pharmacological studies linked to the identification of health benefits. Among the actions determined are its diuretic [13], antidiabetic, antiglycation [14], antioxidant [15], anti-inflammatory [16], and antimicrobial [17] potential. It also has cytotoxic properties [8], is cardioprotective, and inhibits neurodegeneration and modulators of cell signaling [15].

This article presents a bibliographic review focused on the diverse activities that have been attributed to the Eysenhardtia genus, which is made up of fourteen species [18].

\section{Taxonomic Classification}

\section{Kingdom: Plantae \\ Phyllum: Tracheophyta \\ Class: Magnoliopsida \\ Orden: Fabales \\ Family: Fabaceae}

Species: E. adenostylis, E. platycarpa, E. punctata, E. subcoriacea, E. cobriformis, E. reticulata, E. orthocarpa, E. polystachya, E. texana, E. angustifolia, E. spinosa, E. peninsularis, E. parvifolia, E. schizocalyx.

Common names in Mexico: Cuate (Jal.), Coatillo (Pue.), Coatl (l. náhuatl), Cohuatli, Cuatle (Oax.), Lanaé (l. chontalpa, Oax.), Palo cuate, Rosilla (Sin.), Palo dulce (Sin., Mex., Hgo., Pue., Mich.), Palo azul (Mex), Taray (N.L., Dgo.), Tlapahuaxpatli; Ursa (l. otomí, Hgo.), Vara dulce, Varaduz (Dgo.).

Common names in English: Kidneywood, Mexican Kidneywood [19-21].

\subsection{Description of the Eysenhardtia Genus}

The Eysenhardtia genus is a deciduous tree or shrub 3 to $9 \mathrm{~m}$ high with a diameter of 15 to $35 \mathrm{~cm}$ [20]. It has a crown and alternate, compound, pinnate leaves, elliptical leaflets, and aromatic resins. Its wood is branched brown [19]. The bark is rough and scaly with a dark coloration on the outside and reddish-brown on the inside [20]. It shows inflorescences in spiky clusters lobed with white corolla. Its fruit is shown in a curved pod that houses a thin seed susceptible to water, and it is a hermaphrodite (Figure 1) [17].

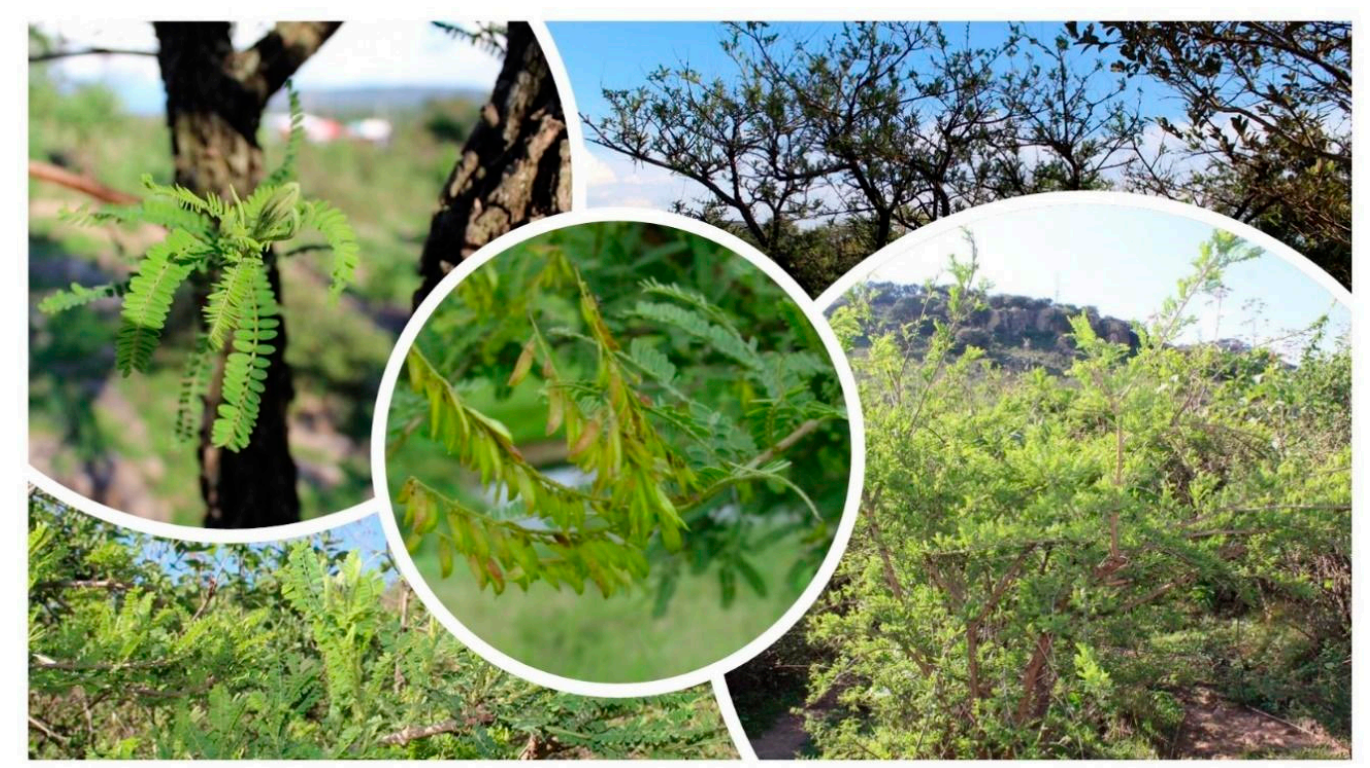

Figure 1. Eysenhardtia genus. 


\subsection{Geographical Distribution of the Eysenhardtia Genus}

It is found throughout Mexico, mainly in the states of Colima, Chiapas, Chihuahua, Coahuila, Mexico City, Durango, Guanajuato, Guerrero, Hidalgo, Jalisco, State of Mexico, Morelos, Oaxaca, Puebla, Querétaro, San Luis Potosí, Sinaloa, Sonora, Tamaulipas, Tlaxcala, Veracruz, and Zacatecas. It has also been found in the southeastern United States (Figure 2) [22,23].

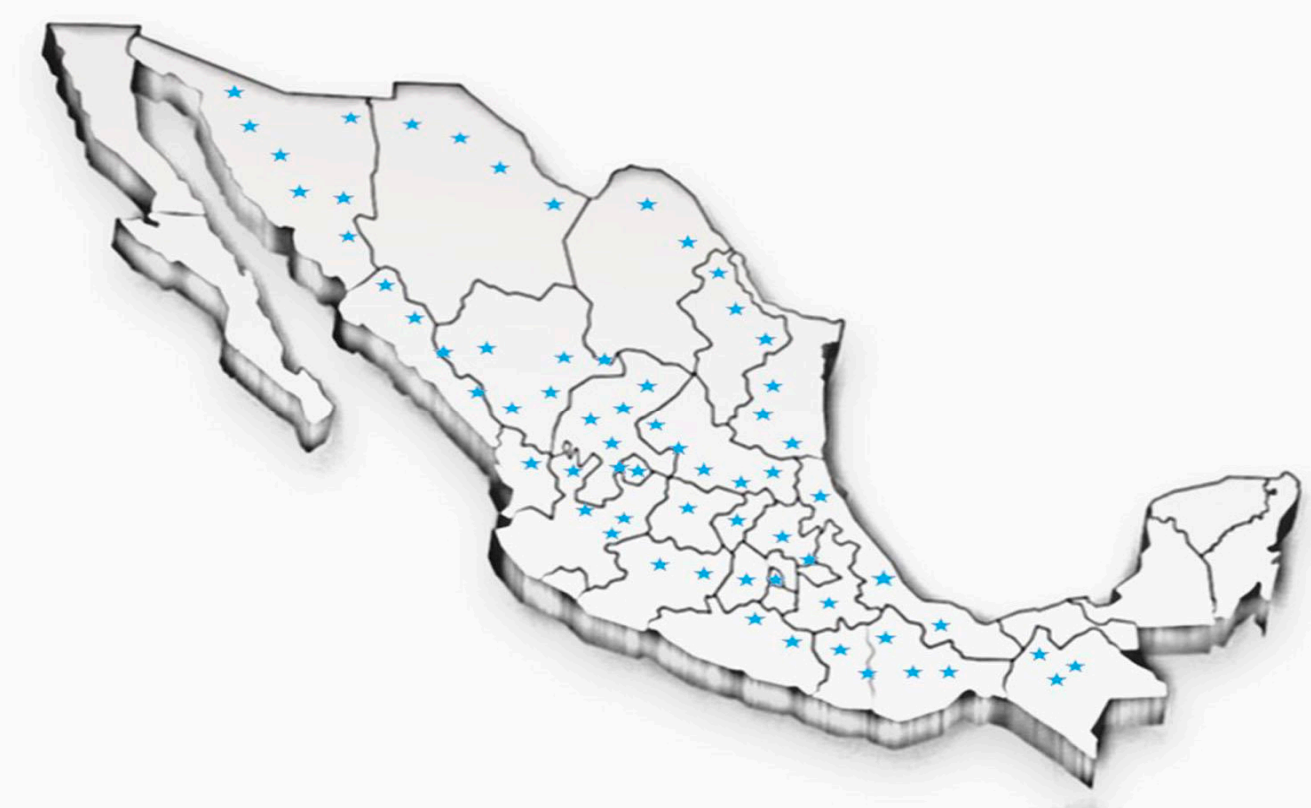

Figure 2. Geographical distribution of Eysenhardtia [22,23].

\section{Secondary Metabolites Isolated from the Eysenhardtia Genus}

The Eysenhardtia genus has shown to be an excellent source of secondary metabolites with flavonoids, flavones, isoflavones, flavonones, phenolic compounds, chalcones, dihydrochalcones, coumarins, pterocarpan, sugars, and fatty acids, among others, in its composition. Table 1 shows the phytochemical compounds identified from the different parts (leaves, branches, heartwood, and bark) of the genus. 
Table 1. Phytochemical compounds identified in the species Eysenhardtia.

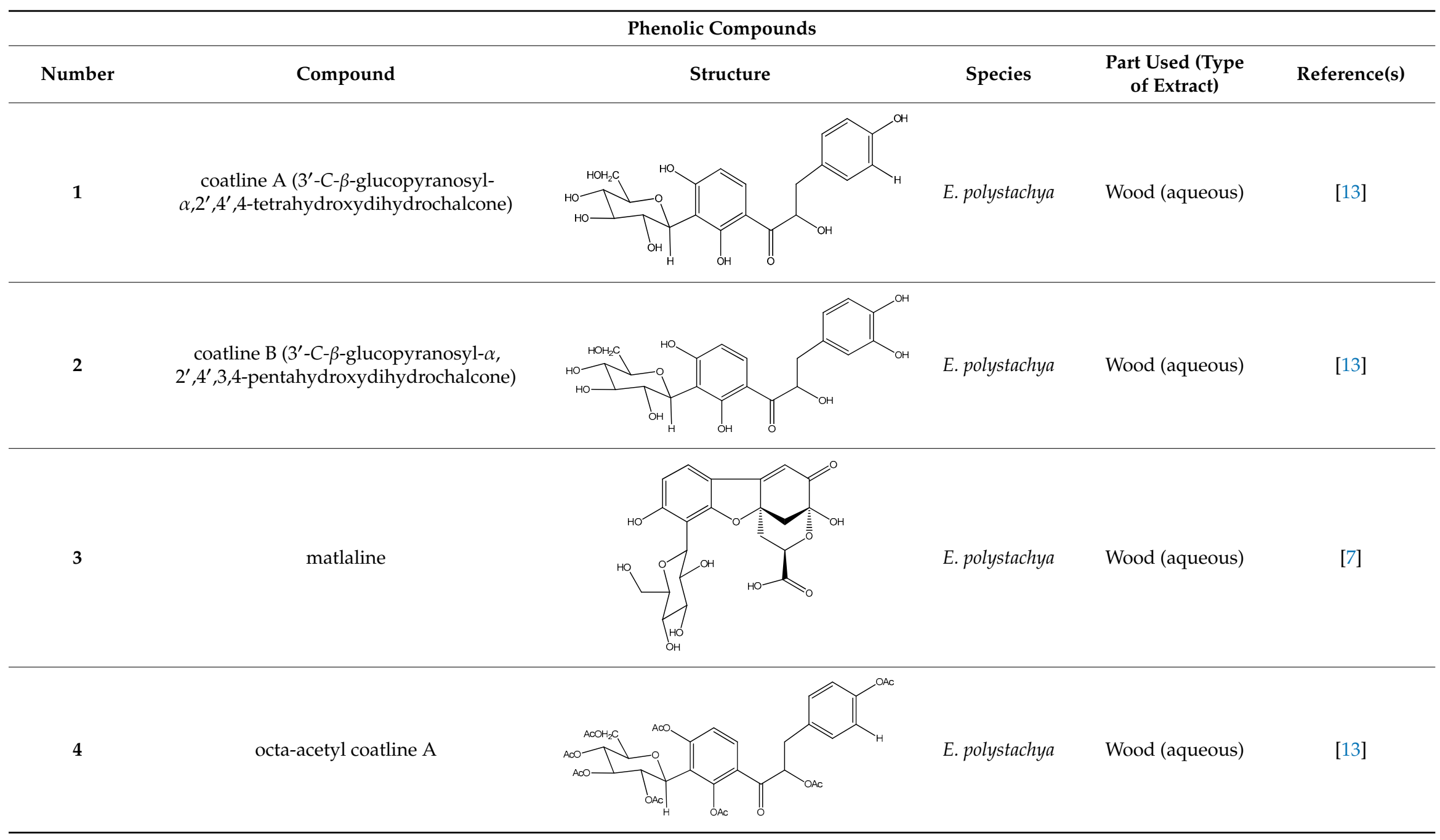


Table 1. Cont

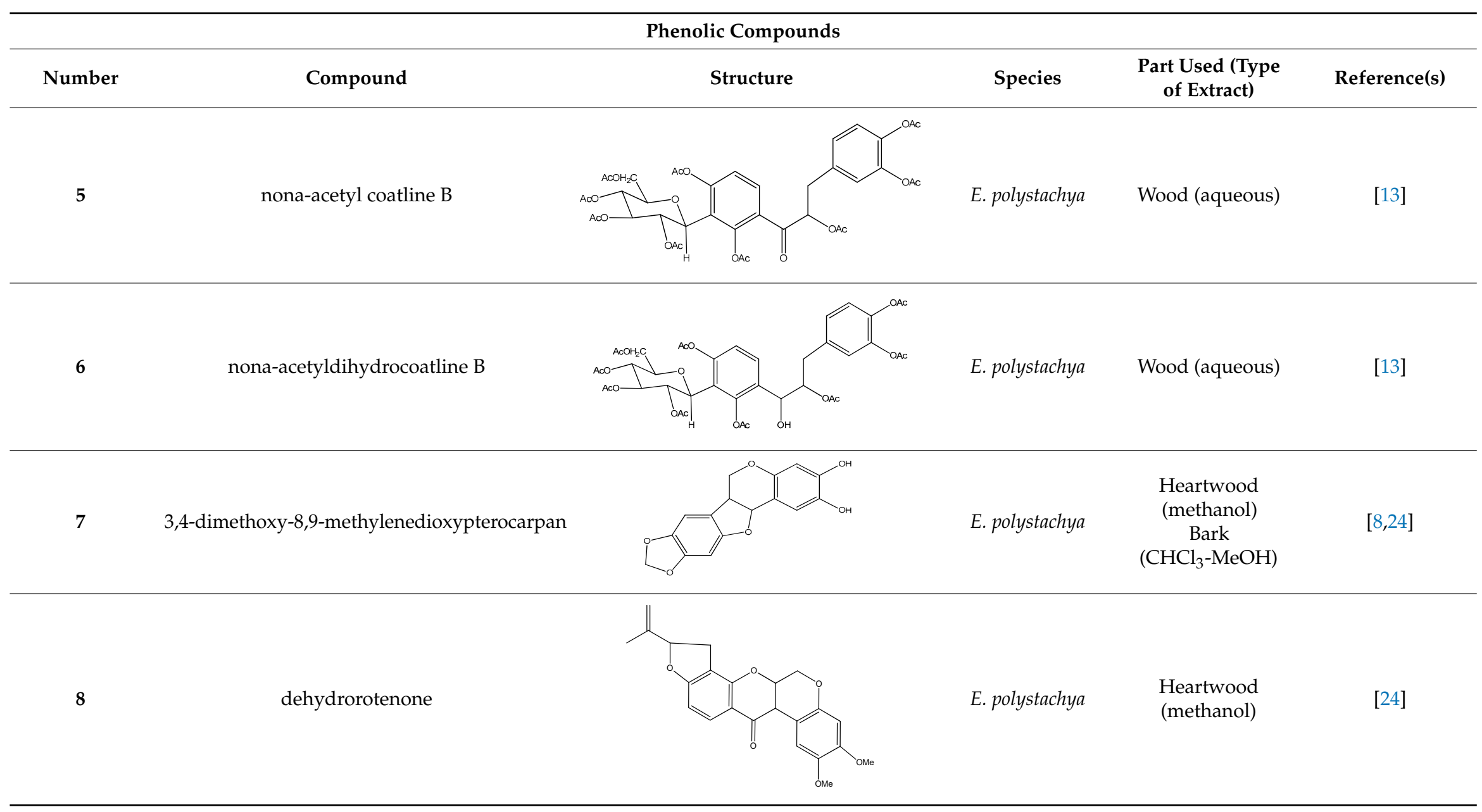


Table 1. Cont.

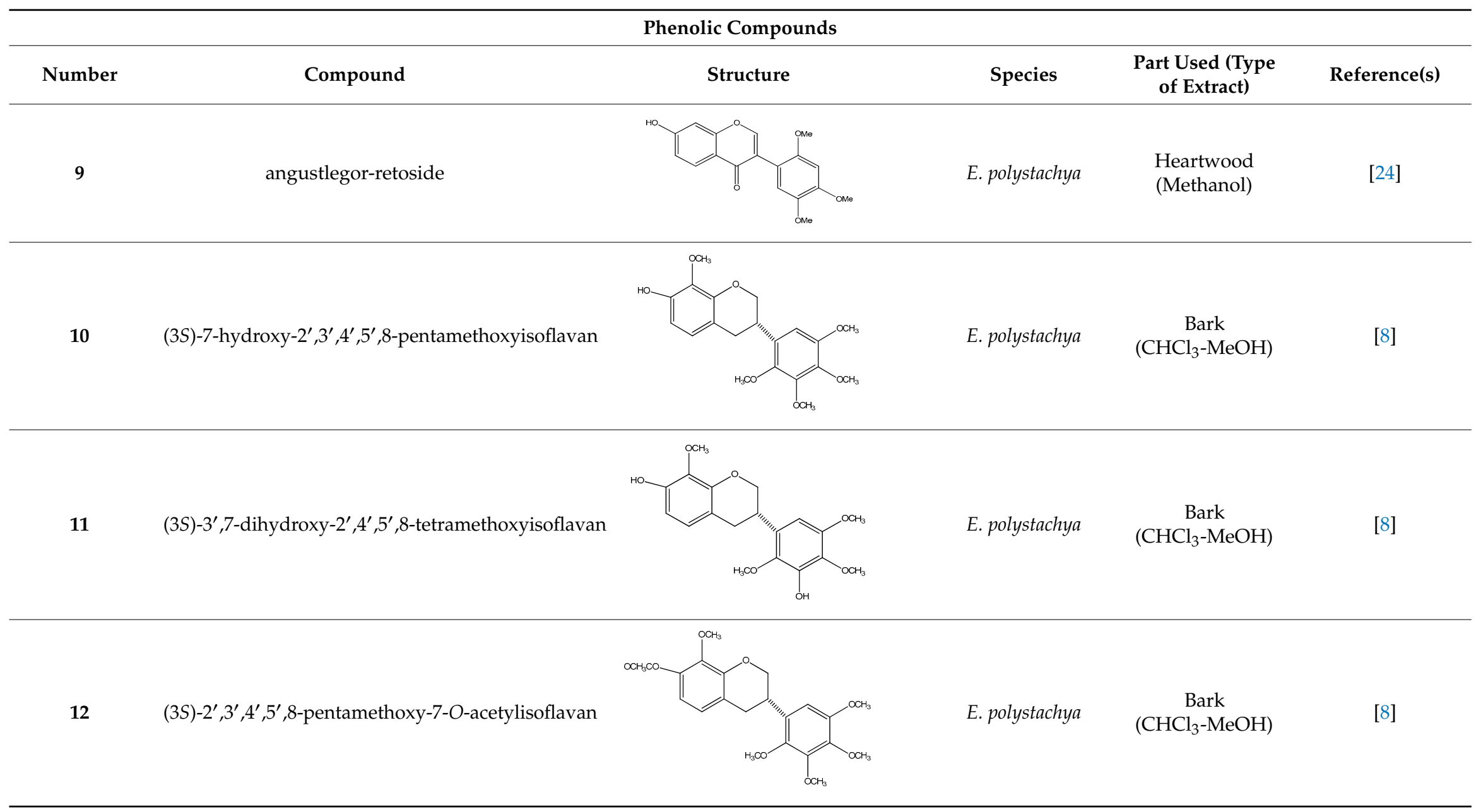


Table 1. Cont

\begin{tabular}{|c|c|c|c|c|c|}
\hline \multicolumn{6}{|c|}{ Phenolic Compounds } \\
\hline Number & Compound & Structure & Species & $\begin{array}{l}\text { Part Used (Type } \\
\text { of Extract) }\end{array}$ & Reference(s) \\
\hline 13 & $\begin{array}{l}(3 S)-2^{\prime}, 4^{\prime}, 5^{\prime}, 8 \text {-tetramethoxy-3',7- } \\
\text { O-diacetylisoflavan }\end{array}$ & & E. polystachya & $\begin{array}{c}\text { Bark } \\
\left(\mathrm{CHCl}_{3}-\mathrm{MeOH}\right)\end{array}$ & [8] \\
\hline 14 & $\begin{array}{c}\text { isoduartin } \\
\left(2^{\prime}, 7 \text {-dihydroxy-3', } 4^{\prime}, 8 \text {-trimethoxyisoflavan }\right)\end{array}$ & & E. polystachya & $\begin{array}{c}\text { Bark } \\
\left(\mathrm{CHCl}_{3}-\mathrm{MeOH}\right)\end{array}$ & [8] \\
\hline 15 & $\begin{array}{l}\text { cuneatin (7-hydroxy-2' -methoxy-4' } 4^{\prime}, 5^{\prime}- \\
\text { (methylendioxy)isoflavone) }\end{array}$ & & E. polystachya & $\begin{array}{c}\text { Bark } \\
\left(\mathrm{CHCl}_{3}-\mathrm{MeOH}\right)\end{array}$ & [8] \\
\hline 16 & 7-hydroxy-2', $4^{\prime}, 5^{\prime}$-trimethoxyisoflavone & & E. polystachya & $\begin{array}{c}\text { Bark } \\
\left(\mathrm{CHCl}_{3}-\mathrm{MeOH}\right) \\
\text { Heartwood } \\
\text { (Aqueous) }\end{array}$ & [8] \\
\hline 17 & $(\alpha-R)-\alpha, 3,4,2^{\prime}, 4^{\prime}$-pentahydroxydihydrochalcone & & E. polystachya & $\begin{array}{c}\text { Bark } \\
\left(\mathrm{CHCl}_{3}-\mathrm{MeOH}\right)\end{array}$ & [25] \\
\hline
\end{tabular}


Table 1. Cont

\begin{tabular}{|c|c|c|c|c|c|}
\hline \multicolumn{6}{|c|}{ Phenolic Compounds } \\
\hline Number & Compound & Structure & Species & $\begin{array}{l}\text { Part Used (Type } \\
\text { of Extract) }\end{array}$ & Reference(s) \\
\hline 18 & $\begin{array}{l}(\alpha R)-3^{\prime}-\mathrm{C}-\beta \text {-D-xylopyranosyl- } \alpha, 3,4,2^{\prime}, 4^{\prime}- \\
\text { pentahydroxydihydrochalcone }\end{array}$ & & E. polystachya & $\begin{array}{c}\text { Bark } \\
\left(\mathrm{CHCl}_{3}-\mathrm{MeOH}\right)\end{array}$ & [25] \\
\hline 19 & $\begin{array}{l}(\alpha R)-3^{\prime}-O-\beta \text {-D-xylopyranosyl- } \alpha, 3,4,2^{\prime}, 4^{\prime}- \\
\text { pentahydroxydihydrochalcone }\end{array}$ & & E. polystachya & $\begin{array}{c}\text { Bark } \\
\left(\mathrm{CHCl}_{3}-\mathrm{MeOH}\right)\end{array}$ & [25] \\
\hline 20 & $\begin{array}{l}\text { 4',5,7-trihydroxy-8-methyl-6-(3-methyl- } \\
\text { [2-butenyl])-(2S)-flavanone }\end{array}$ & & E. texana & $\begin{array}{c}\text { Aerial parts } \\
\left(\mathrm{CH}_{2} \mathrm{Cl}_{2}-\mathrm{MeOH}\right)\end{array}$ & {$[26,27]$} \\
\hline 21 & $\begin{array}{l}\text { 4',5,7-trihydroxy-6-methyl-8-(3-methyl- } \\
\text { [2-butenyl])-(2S)-flavanone }\end{array}$ & & E. texana & $\begin{array}{c}\text { Aerial parts } \\
\left(\mathrm{CH}_{2} \mathrm{Cl}_{2}-\mathrm{MeOH}\right)\end{array}$ & {$[26,27]$} \\
\hline
\end{tabular}


Table 1. Cont

\begin{tabular}{|c|c|c|c|c|c|}
\hline \multicolumn{6}{|c|}{ Phenolic Compounds } \\
\hline Number & Compound & Structure & Species & $\begin{array}{l}\text { Part Used (Type } \\
\text { of Extract) }\end{array}$ & Reference(s) \\
\hline 22 & $\begin{array}{l}\text { 4',5-dihydroxy-7-methoxy-6-(3-methyl- } \\
\text { [2-butenyl])-(2S)-flavanone }\end{array}$ & & E. texana & $\begin{array}{c}\text { Aerial parts } \\
\left(\mathrm{CH}_{2} \mathrm{Cl}_{2}-\mathrm{MeOH}\right)\end{array}$ & {$[26,27]$} \\
\hline 23 & 7-hydroxy-4'-methoxyisoflavone & & E. polystachya & $\begin{array}{l}\text { Heartwood } \\
\text { (Aqueous) }\end{array}$ & {$[28,29]$} \\
\hline 24 & $4^{\prime}$-O-methyl-8-prenylnaringenin & & E. platycarpa & $\begin{array}{c}\text { Leaves } \\
\text { (Methanolic) }\end{array}$ & [30] \\
\hline 25 & $\begin{array}{l}5,4^{\prime}, 1^{\prime \prime} \text {-trihydroxy-6,7-(3", } 3^{\prime \prime}- \\
\text { dimethylchroman)flavone }\end{array}$ & & E. platycarpa & $\begin{array}{l}\text { Branches } \\
\text { (Methanolic) }\end{array}$ & [30] \\
\hline
\end{tabular}


Table 1. Cont

\begin{tabular}{|c|c|c|c|c|c|}
\hline \multicolumn{6}{|c|}{ Phenolic Compounds } \\
\hline Number & Compound & Structure & Species & $\begin{array}{l}\text { Part Used (Type } \\
\text { of Extract) }\end{array}$ & Reference(s) \\
\hline 26 & (2S)-4'-O-methyl-6-methyl-8-prenylnaringenin & & E. platycarpa & $\begin{array}{l}\text { Branches and } \\
\text { leaves } \\
\text { (Methanolic) }\end{array}$ & {$[30]$} \\
\hline 27 & 5,7-dihydroxy-6-methyl-8-prenylflavanone & & E. platycarpa & $\begin{array}{c}\text { Branches and } \\
\text { leaves } \\
\text { (Methanolic) }\end{array}$ & {$[30]$} \\
\hline 28 & 5,7-dihydroxy-8-methyl-6-prenylflavanone & & E. platycarpa & $\begin{array}{c}\text { Branches and } \\
\text { leaves } \\
\text { (Methanolic) }\end{array}$ & [30] \\
\hline 29 & 5,7-dihydroxy-6-prenylflavanone & & E. platycarpa & $\begin{array}{c}\text { Branches } \\
\text { (Methanolic) }\end{array}$ & {$[30]$} \\
\hline
\end{tabular}


Table 1. Cont

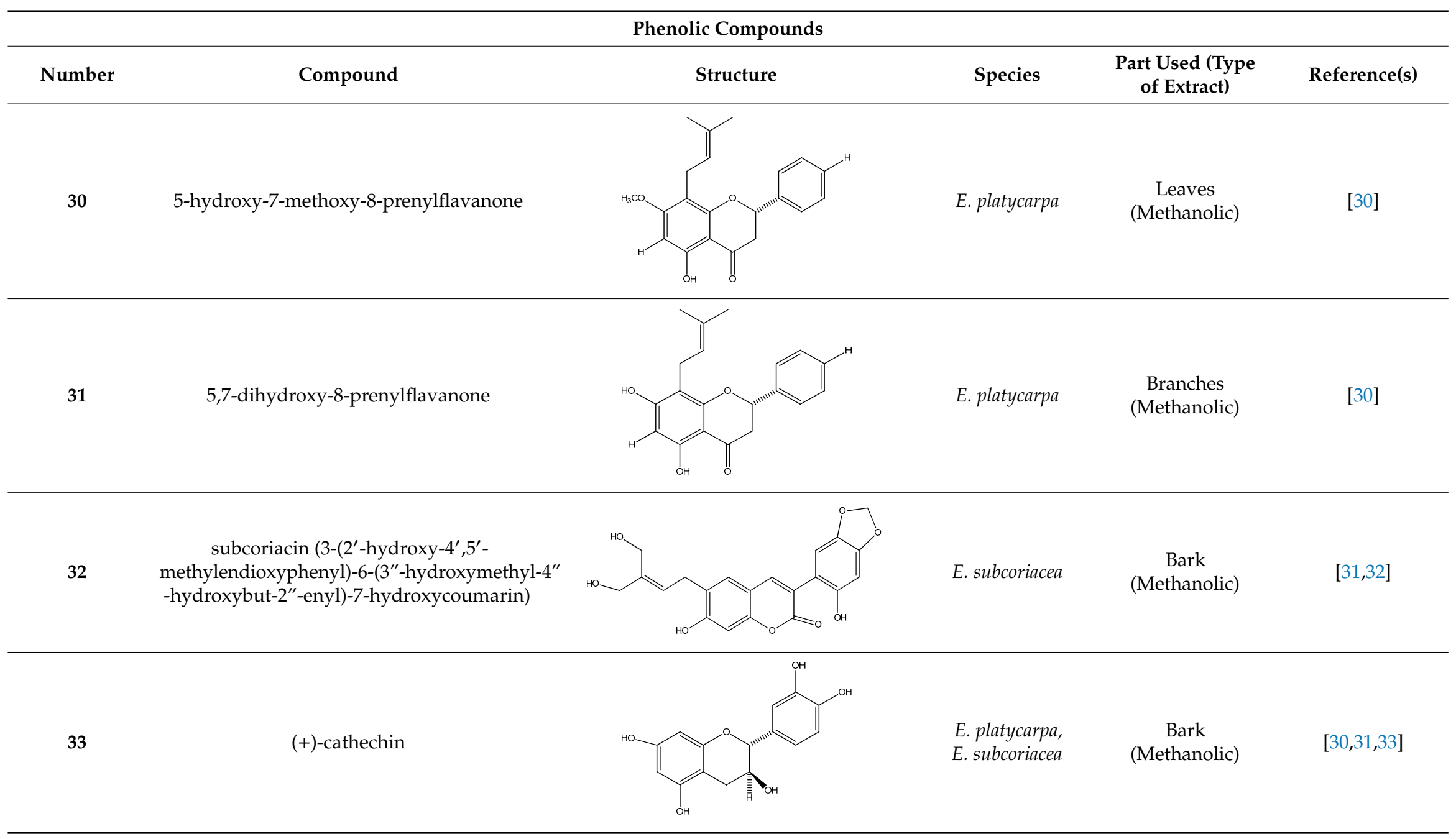


Table 1. Cont

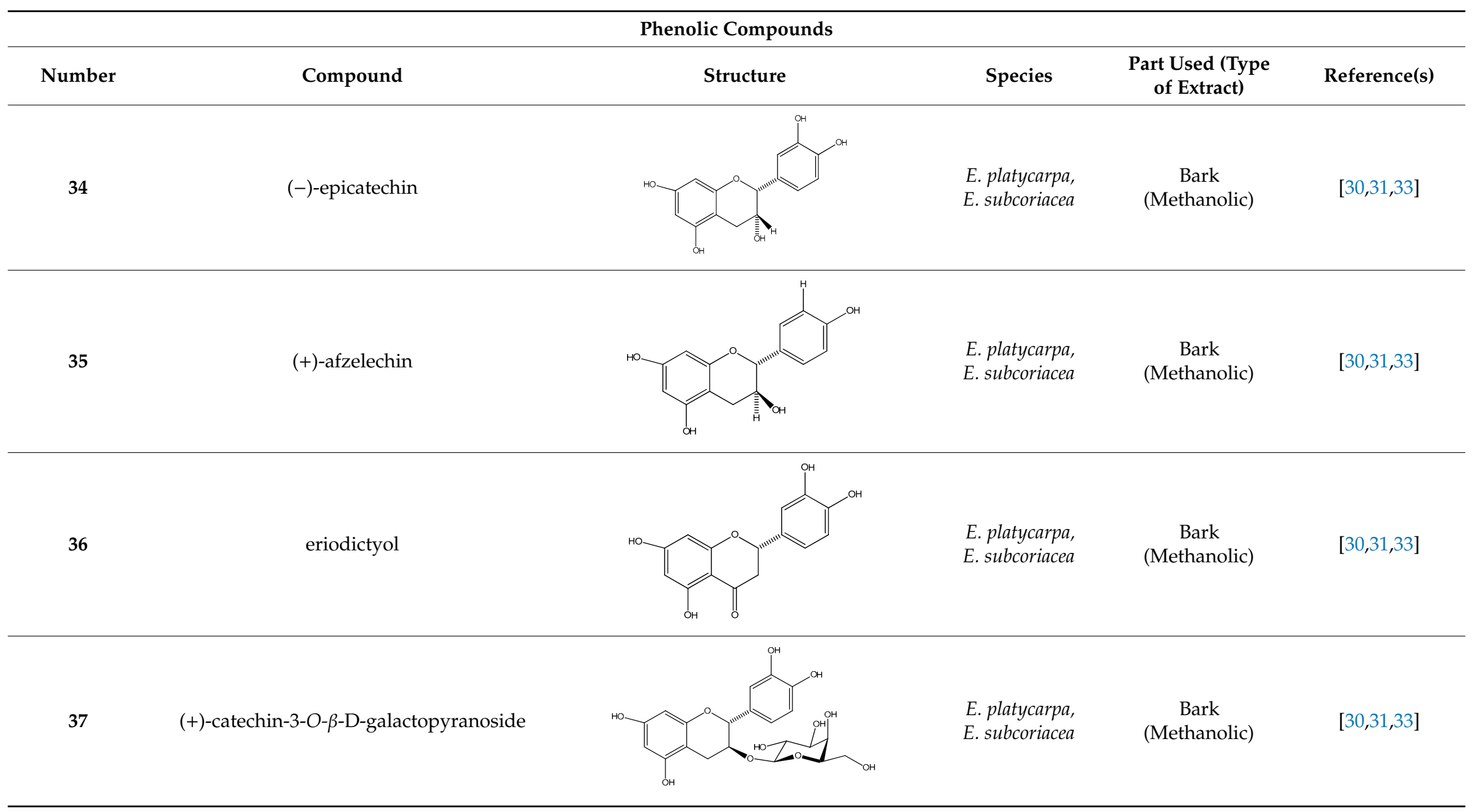


Table 1. Cont.

\begin{tabular}{|c|c|c|c|c|c|}
\hline \multicolumn{6}{|c|}{ Phenolic Compounds } \\
\hline Number & Compound & Structure & Species & $\begin{array}{l}\text { Part Used (Type } \\
\text { of Extract) }\end{array}$ & Reference(s) \\
\hline 38 & quercetin-3-O- $\beta$-D-galactopyranoside & & $\begin{array}{l}\text { E. platycarpa, } \\
\text { E. subcoriacea }\end{array}$ & $\begin{array}{c}\text { Bark } \\
\text { (Methanolic) }\end{array}$ & {$[30,31,33]$} \\
\hline 39 & $2^{\prime}, 4^{\prime}$-dihydroxychalcone- $6^{\prime}-O-\beta$-D-glucopyranoside & & E. polystachya & $\begin{array}{c}\text { Bark } \\
\text { (Water/MeOH) }\end{array}$ & [34] \\
\hline 40 & $\begin{array}{c}\alpha, 3,2^{\prime}, 4^{\prime} \text {-tetrahydroxy-4-methoxy- } \\
\text { dihydrochalcone- } 3^{\prime} \text {-C- } \beta \text {-glucopyranosy- } \\
\quad 6^{\prime}-O-\beta \text {-D-glucopyranoside }\end{array}$ & & E. polystachya & $\begin{array}{c}\text { Bark } \\
\text { (Water/MeOH) }\end{array}$ & [34] \\
\hline 41 & $\begin{array}{l}\text { 7-hydroxy-5, } 8^{\prime} \text {-dimethoxy- } 6^{\prime} \alpha-L- \\
\text { rhamnopyranosyl-8-(3-phenyl-transacryloyl)- } \\
\text { 1-benzopyran-2-one }\end{array}$ & & E. polystachya & $\begin{array}{c}\text { Bark } \\
\text { (Water/MeOH) }\end{array}$ & {$[34]$} \\
\hline
\end{tabular}


Table 1. Cont.

\begin{tabular}{|c|c|c|c|c|c|}
\hline \multicolumn{6}{|c|}{ Phenolic Compounds } \\
\hline Number & Compound & Structure & Species & $\begin{array}{l}\text { Part Used (Type } \\
\text { of Extract) }\end{array}$ & Reference(s) \\
\hline 42 & $\begin{array}{l}\text { 6',7-dihydroxy-5,8-dimethoxy-8(3-phenyl-trans- } \\
\text { acryloyl)-1-benzopyran-2-one }\end{array}$ & & E. polystachya & $\begin{array}{c}\text { Bark } \\
\text { (Water/MeOH) }\end{array}$ & [34] \\
\hline 43 & 9-hydroxy-3,8-dimethoxy-4-prenylpterocarpan & & E. polystachya & $\begin{array}{c}\text { Bark } \\
\text { (Water/MeOH) }\end{array}$ & [34] \\
\hline 44 & 5,4'-dihydroxy-7, 2' -dimethoxyl-isoflavone & & E. polystachya & $\begin{array}{c}\text { Bark } \\
\text { (Water/MeOH) }\end{array}$ & [34] \\
\hline 45 & $\begin{array}{c}\alpha, 4,4^{\prime} \text {-trihydroxy-dihydrochalcone-2' } \\
\text { O- } \beta \text {-D-glucopyranoside }\end{array}$ & & E. polystachya & $\begin{array}{c}\text { Bark } \\
\text { (Water/MeOH) }\end{array}$ & [34] \\
\hline
\end{tabular}


Table 1. Cont.

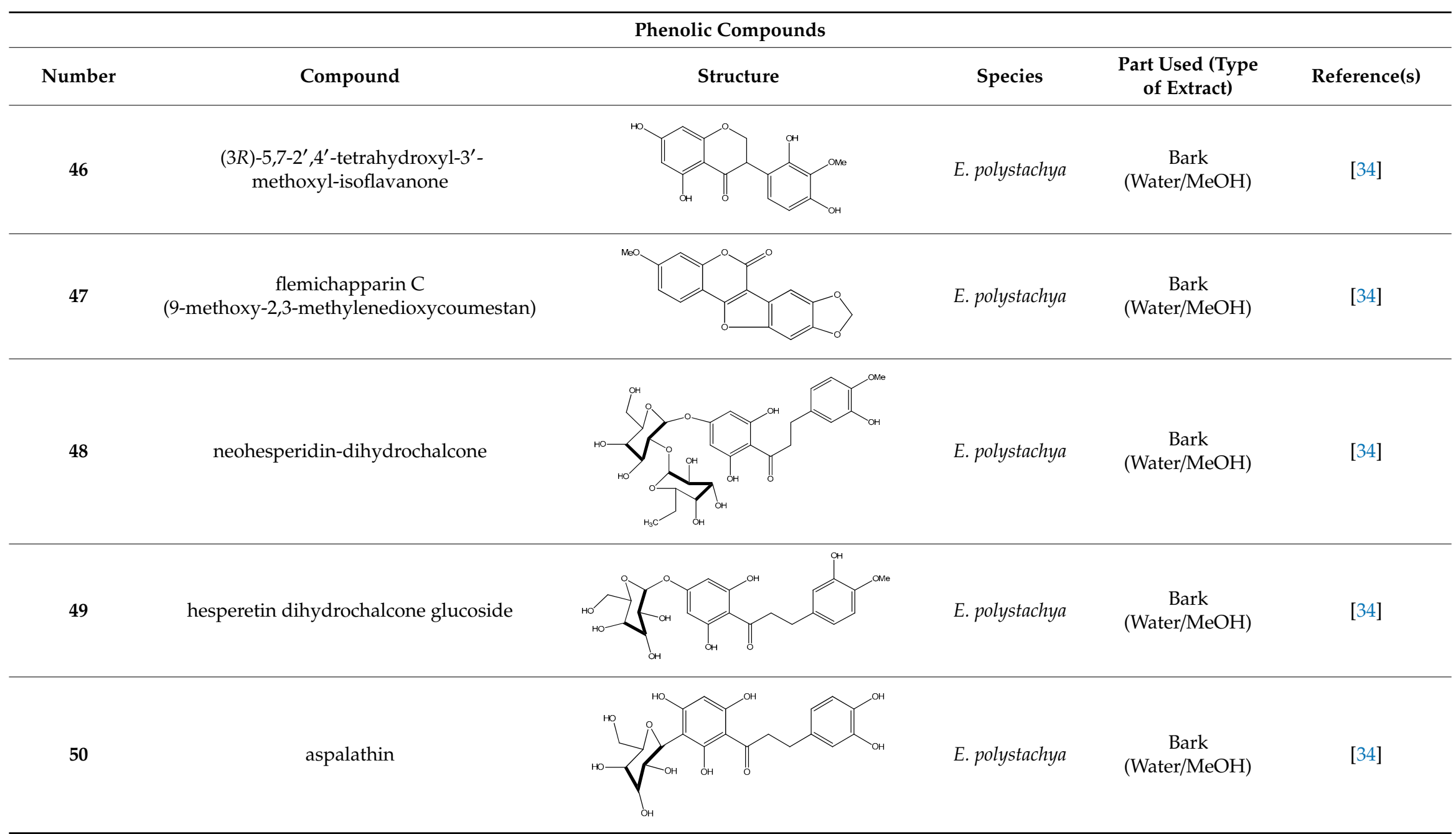


Table 1. Cont

\begin{tabular}{|c|c|c|c|c|c|}
\hline \multicolumn{6}{|c|}{ Phenolic Compounds } \\
\hline Number & Compound & Structure & Species & $\begin{array}{l}\text { Part Used (Type } \\
\text { of Extract) }\end{array}$ & Reference(s) \\
\hline 51 & sandwicensin & & E. polystachya & $\begin{array}{c}\text { Bark } \\
\text { (Water/MeOH) }\end{array}$ & {$[34]$} \\
\hline 52 & $\begin{array}{c}2^{\prime} \text {-O- } \alpha \text {-L-rhamnopyranosyl- } \alpha, 6^{\prime} \text {-dihydroxy- } \\
4^{\prime} \text {-acetyl-4-methoxydihydrochalcone }\end{array}$ & & E. polystachya & $\begin{array}{c}\text { Bark } \\
\text { (Water/MeOH) }\end{array}$ & [35] \\
\hline 53 & $6^{\prime}$ methoxy-sieboldin & & E. polystachya & $\begin{array}{c}\text { Bark } \\
\text { (Water/MeOH) }\end{array}$ & [35] \\
\hline 54 & $\begin{array}{l}2^{\prime} \text {-O- } \beta \text {-D-glucopyranosyl-4'-methoxy-4- } \\
\text { hydroxy-3-isoprenyldihydrochalcone }\end{array}$ & & E. polystachya & $\begin{array}{c}\text { Bark } \\
\text { (Water/MeOH) }\end{array}$ & [35] \\
\hline
\end{tabular}


Table 1. Cont.

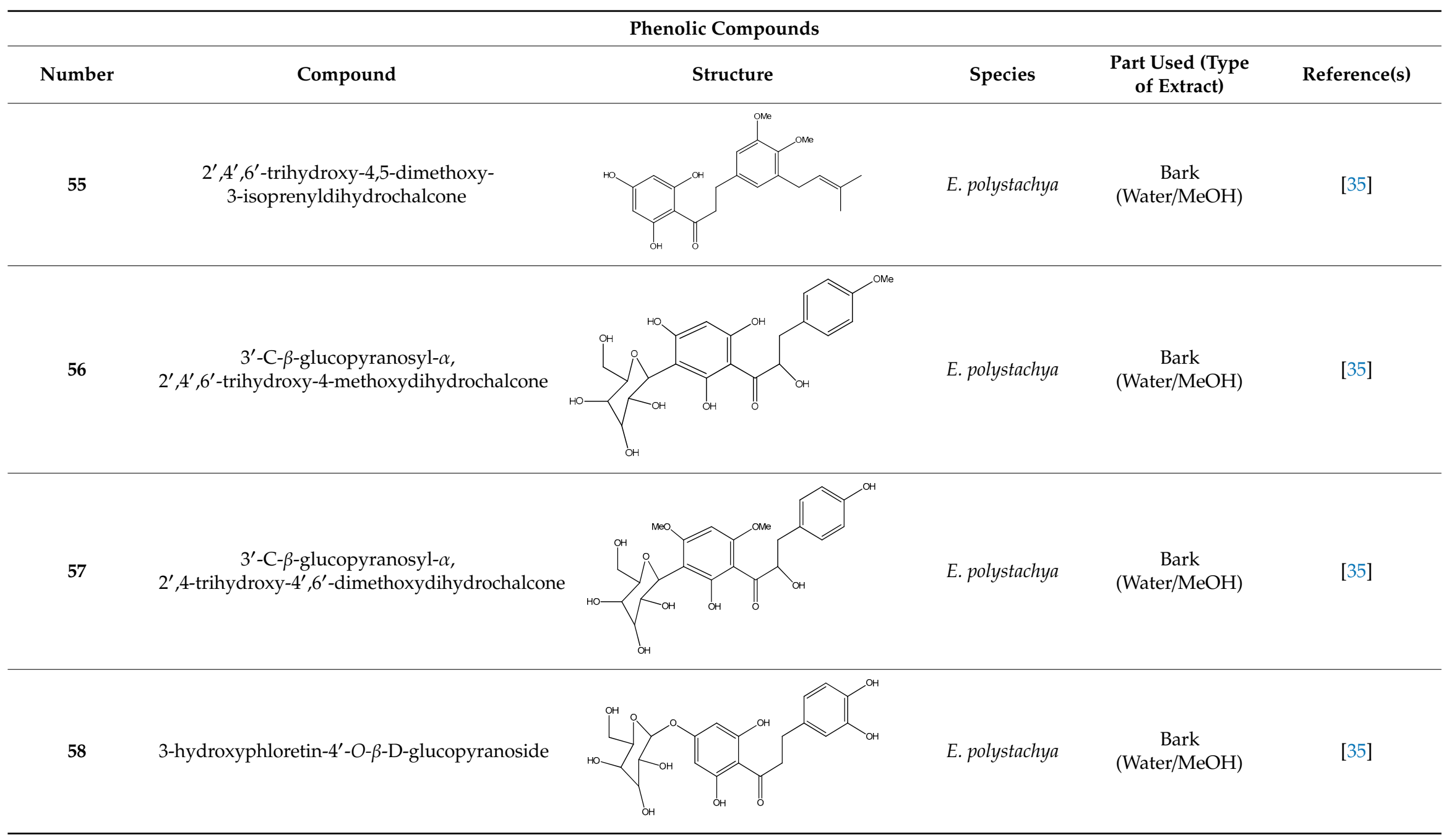


Table 1. Cont

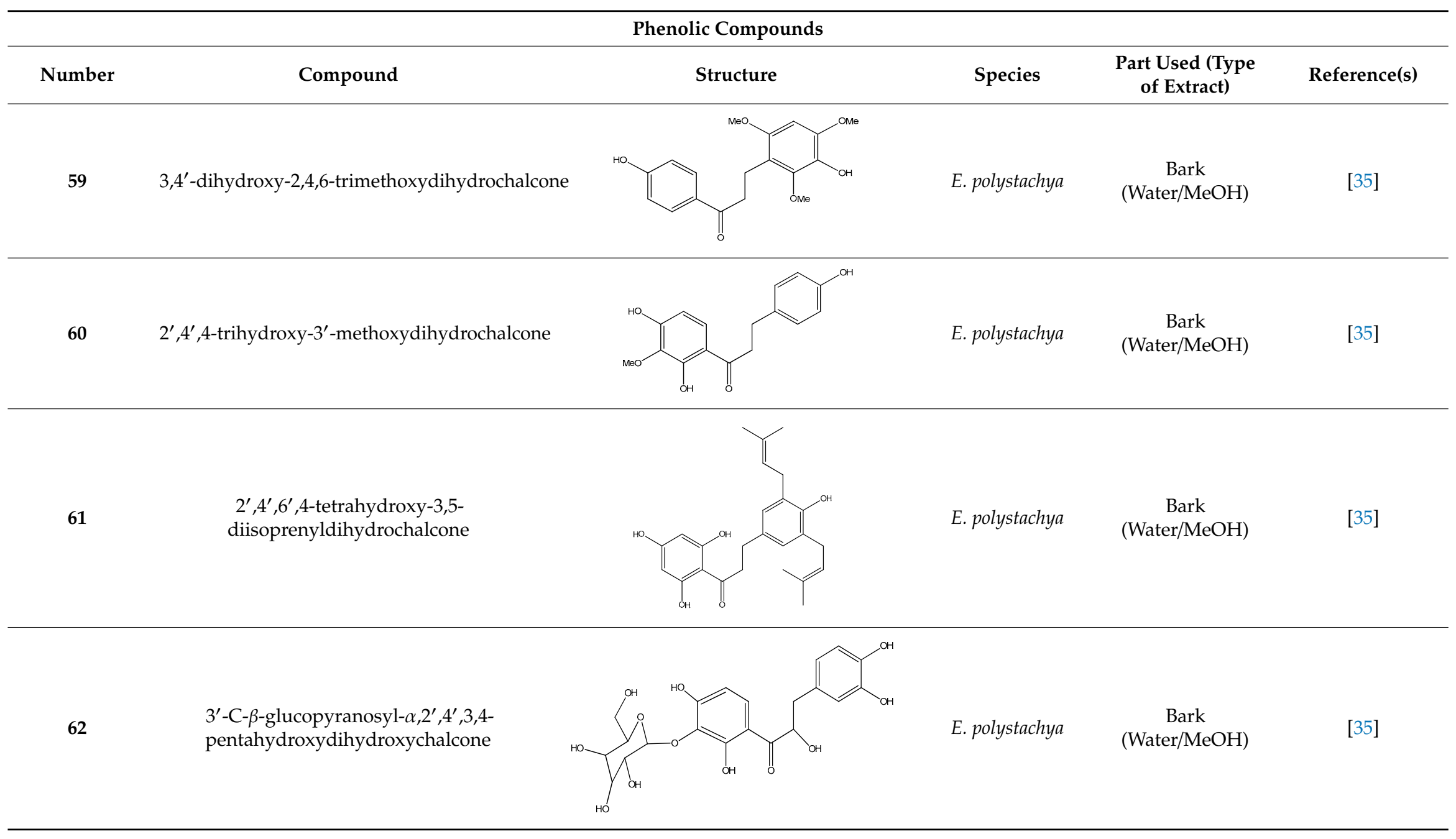


Table 1. Cont

\begin{tabular}{|c|c|c|c|c|c|}
\hline \multicolumn{6}{|c|}{ Phenolic Compounds } \\
\hline Number & Compound & Structure & Species & $\begin{array}{l}\text { Part Used (Type } \\
\text { of Extract) }\end{array}$ & Reference(s) \\
\hline 63 & $\begin{array}{l}3^{\prime} \text {-O- } \beta \text {-D-glucopyranosyl- } \alpha, 4,2^{\prime}, 4^{\prime}, 6^{\prime}- \\
\text { pentahydroxydihydrochalcone }\end{array}$ & & E. polystachya & $\begin{array}{c}\text { Bark } \\
\text { (Water/MeOH) }\end{array}$ & [36] \\
\hline \multicolumn{6}{|c|}{ Sterols and terpenoids } \\
\hline 64 & oleanolic acid & & E. platycarpa & $\begin{array}{c}\text { Branches } \\
\text { (Methanolic) }\end{array}$ & [30] \\
\hline 65 & $\beta$-sitosterol & & E. platycarpa & $\begin{array}{l}\text { Branches } \\
\text { (methanolic) }\end{array}$ & {$[30]$} \\
\hline
\end{tabular}


Table 1. Cont.

\begin{tabular}{|c|c|c|c|c|c|}
\hline \multicolumn{6}{|c|}{ Sterols and terpenoids } \\
\hline Number & Compound & Structure & Species & $\begin{array}{l}\text { Part Used (Type } \\
\text { of Extract) }\end{array}$ & Reference(s) \\
\hline 66 & $\beta$-sitosteryl $\beta$-D-glucopyranoside & & E. platycarpa & $\begin{array}{l}\text { Branches } \\
\text { (Methanolic) }\end{array}$ & [30] \\
\hline 67 & $\beta$-sitosteryl palmitate & & E. platycarpa & $\begin{array}{c}\text { Branches } \\
\text { (Methanolic) }\end{array}$ & {$[30]$} \\
\hline 68 & stigmasterol & & E. polystachya & $\begin{array}{c}\text { Bark } \\
\left(\mathrm{CHCl}_{3}-\mathrm{MeOH}\right)\end{array}$ & [8] \\
\hline
\end{tabular}


Table 1. Cont.

\begin{tabular}{|c|c|c|c|c|c|}
\hline \multicolumn{6}{|c|}{ Sterols and terpenoids } \\
\hline Number & Compound & Structure & Species & $\begin{array}{l}\text { Part Used (Type } \\
\text { of Extract) }\end{array}$ & Reference(s) \\
\hline 69 & 3-O-acetyl-11 $\alpha, 12 \alpha$-epoxy-oleanan-28,13 $\beta$-olide & & E. platycarpa & $\begin{array}{l}\text { Branches } \\
\text { (Methanolic) }\end{array}$ & {$[30,33]$} \\
\hline 70 & lupeol & & E. platycarpa & $\begin{array}{l}\text { Branches } \\
\text { (Methanolic) }\end{array}$ & [30] \\
\hline 71 & betulinic acid & & E. platycarpa & $\begin{array}{l}\text { Branches } \\
\text { (Methanolic) }\end{array}$ & [30] \\
\hline
\end{tabular}


Table 1. Cont.

\begin{tabular}{|c|c|c|c|c|c|}
\hline \multicolumn{6}{|c|}{ Sterols and terpenoids } \\
\hline Number & Compound & Structure & Species & $\begin{array}{l}\text { Part Used (Type } \\
\text { of Extract) }\end{array}$ & Reference(s) \\
\hline 72 & 3-O-acetyloleanolic acid & & E. platycarpa & $\begin{array}{l}\text { Branches and } \\
\text { leaves } \\
\text { (Methanolic) }\end{array}$ & {$[30]$} \\
\hline \multicolumn{6}{|c|}{ Fatty acids } \\
\hline 73 & stearic acid & & E. polystachya & $\begin{array}{c}\text { Branches and } \\
\text { leaves } \\
\text { (Ethanolic) }\end{array}$ & [12] \\
\hline 74 & arachidic acid & & E. polystachya & $\begin{array}{c}\text { Branches and } \\
\text { leaves } \\
\text { (Ethanolic) }\end{array}$ & [12] \\
\hline 75 & palmitic acid & & E. polystachya & $\begin{array}{c}\text { Branches and } \\
\text { leaves } \\
\text { (Ethanolic) }\end{array}$ & [12] \\
\hline 76 & linoleic acid & & E. polystachya & $\begin{array}{c}\text { Branches and } \\
\text { leaves } \\
\text { (Ethanolic) }\end{array}$ & [12] \\
\hline
\end{tabular}


Table 1. Cont

\begin{tabular}{|c|c|c|c|c|c|}
\hline \multicolumn{6}{|c|}{ Hydroxybenzene } \\
\hline Number & Compound & Structure & Species & $\begin{array}{l}\text { Part Used (Type } \\
\text { of Extract) }\end{array}$ & Reference(s) \\
\hline 77 & syringol & & E. polystachya & $\begin{array}{c}\text { Branches and } \\
\text { leaves } \\
\text { (Ethanolic) }\end{array}$ & [12] \\
\hline 78 & catechol & & E. polystachya & $\begin{array}{c}\text { Branches and } \\
\text { leaves } \\
\text { (Ethanolic) }\end{array}$ & [12] \\
\hline \multicolumn{6}{|c|}{ Cyclohexane } \\
\hline 79 & 3-O-methyl-myo-inositol & & E. platycarpa & $\begin{array}{c}\text { Branches } \\
\text { (Methanolic) }\end{array}$ & {$[30]$} \\
\hline 80 & D-pinitol & & E. polystachya & $\begin{array}{c}\text { Branches and } \\
\text { leaves } \\
\text { (Ethanolic) }\end{array}$ & [12] \\
\hline 81 & lactic acid & & E. polystachya & $\begin{array}{c}\text { Branches and } \\
\text { leaves } \\
\text { (Ethanolic) }\end{array}$ & [12] \\
\hline 82 & 2-furoic acid & & E. polystachya & $\begin{array}{c}\text { Branches and } \\
\text { leaves } \\
\text { (Ethanolic) }\end{array}$ & [12] \\
\hline
\end{tabular}


Table 1. Cont.

\begin{tabular}{|c|c|c|c|c|c|}
\hline \multicolumn{6}{|c|}{ Cyclohexane } \\
\hline Number & Compound & Structure & Species & $\begin{array}{l}\text { Part Used (Type } \\
\text { of Extract) }\end{array}$ & Reference(s) \\
\hline 83 & succinic acid & & E. polystachya & $\begin{array}{c}\text { Branches and } \\
\text { leaves } \\
\text { (Ethanolic) }\end{array}$ & [12] \\
\hline 84 & fumaric acid & & E. polystachya & $\begin{array}{c}\text { Branches and } \\
\text { leaves } \\
\text { (Ethanolic) }\end{array}$ & [12] \\
\hline 85 & sinapic acid & & E. polystachya & $\begin{array}{c}\text { Branches and } \\
\text { leaves } \\
\text { (Ethanolic) }\end{array}$ & [12] \\
\hline 86 & $\mathrm{~N}, \mathrm{~N}$-diethyl carbamate & & E. polystachya & $\begin{array}{c}\text { Branches and } \\
\text { leaves } \\
\text { (Ethanolic) }\end{array}$ & [12] \\
\hline \multicolumn{6}{|c|}{ Carbohydrates or saccharides } \\
\hline 87 & D-erythrose & & E. polystachya & $\begin{array}{c}\text { Branches and } \\
\text { leaves } \\
\text { (Ethanolic) }\end{array}$ & [12] \\
\hline 88 & D-mannose & & E. polystachya & $\begin{array}{c}\text { Branches and } \\
\text { leaves } \\
\text { (Ethanolic) }\end{array}$ & [12] \\
\hline
\end{tabular}


Table 1. Cont.

\begin{tabular}{|c|c|c|c|c|c|}
\hline \multicolumn{6}{|c|}{ Carbohydrates or saccharides } \\
\hline Number & Compound & Structure & Species & $\begin{array}{l}\text { Part Used (Type } \\
\text { of Extract) }\end{array}$ & Reference(s) \\
\hline 89 & D-arabinose & & E. polystachya & $\begin{array}{c}\text { Branches and } \\
\text { leaves } \\
\text { (Ethanolic) }\end{array}$ & [12] \\
\hline 90 & xilose & & E. polystachya & $\begin{array}{c}\text { Branches and } \\
\text { leaves } \\
\text { (Ethanolic) }\end{array}$ & [12] \\
\hline 91 & trehalose & & E. polystachya & $\begin{array}{c}\text { Branches and } \\
\text { leaves } \\
\text { (Ethanolic) }\end{array}$ & [12] \\
\hline
\end{tabular}




\section{Pharmacological Activities}

The pharmacological activities were described chronologically in order to encapsulate the research carried out on Eysenhardtia gender through the years.

\subsection{Urinary Disorders}

As previously mentioned, the plant was analyzed for its beneficial effects on kidney or urinary tract problems. In 1998 carried out a study to test the diuretic and antilytic effect of the aqueous extract of Eysenhardtia polystachya bark in rats [37]. The model animals were induced with urolithiasis by implanting a zinc disk in the bladder. As a result, they observed a significant reduction in the weight of the uroliths after the administration of the aqueous extract of E. polystachya in the affected animals compared to the control group. Diuretic action was also verified by identifying an increase in the volume of urine [37], as well as favoring the retention of potassium [38].

In the year 2000, the compounds responsible for the antiurolithiatic (antilithiatic) and diuretic activity were identified, which correspond to 7-hydroxy-2' $4^{\prime}, 5^{\prime}$-trimethoxyisoflavone (16) and 7-hydroxy-4'-methoxyisoflavone (23) [28,39].

Later, in 2002, the effect of isoflavones isolated from the bark of Eysenhardtia polystachya on the formation of oxalate and calcium phosphate (COM) stones in urine was analyzed and reported in a preclinical trial. From this study, it was found that the phenolics compounds reported were able to inhibit the formation and growth of COM, consequently reducing the appearance of kidney stones and suggesting the use of isoflavones as a preventive treatment [29].

\subsection{Antimicrobial Activity}

The inappropriate use of treatments and the ability of microorganisms to adapt have led them to develop tolerance to various antimicrobial drugs; this has prompted the continued search for new drugs that offer other options, possible sources thereof being plants. In the case of the genus Eysenhardtia, the first report found on antimicrobial activity was published in 1997, in which an antimicrobial scan was performed using minimal inhibitory concentration (MIC) tests. The microorganisms used were Sarcina lutea, Proteus vulgaris, Staphylococcus aureus, Escherichia coli, and Candida albicans. The information obtained showed that the E. polystachya methanol extract had an effect on inhibiting the different strains studied; this inhibitory action was shown to have potential against Gram positive and Gram negative bacteria [40].

In 1998, the antimicrobial action of the compounds (3S)-7-hydroxy- $2^{\prime}, 3^{\prime}, 4^{\prime}, 5^{\prime}, 8$-pentamethoxyisoflavan (10), (3S)-3',7-dihydroxy-2', $4^{\prime}, 5^{\prime}, 8$-tetramethoxyisoflavan (11), stigmasterol (68), isoduartin (14), cuneatin (15), 7-hydroxy-2', 4', $5^{\prime}$-trimethoxyisoflavone (16) and 3,4-dimethoxy-8,9-methylenedioxypterocarpan (7), isolated from the bark E. polystachya was analyzed for each of it. The results showed that they had no action against Escherichia coli, Pseudomonas aeroginosa, Streptococcus aureus, Bacillus subtilis, Shigella smiled, and Candida albicans at a concentration of $200 \mu \mathrm{g} / \mathrm{mL}$ [8].

In 1999, the compounds ( $\alpha$-hydroxydihydrochalcones, $(\alpha R)-\alpha, 3,4,2^{\prime}, 4^{\prime}$-pentahydroxydihydrochalcone (17), $\quad(\alpha R)-3^{\prime}-\mathrm{C}-\beta$-D-xylopyranosyl- $\alpha, 3,4,2^{\prime}, 4^{\prime}$-pentahydroxydihydrochalcone $\quad(18), \quad(\alpha R)-3^{\prime}-O-\beta$-Dxylopyranosyl- $\alpha, 3,4,2^{\prime}, 4^{\prime}$-pentahydroxydihydrochalcone (19) and coatline B [( $\left.\alpha R\right)-3^{\prime}-\mathrm{C}-\beta$ - D-glucopyranosyl- $\alpha$, 2',3,4',4-pentahydroxydihydrochalcone]) (2) isolated from the bark of E. polystachya. They did not show activity against Escherichia coli, Pseudomonas aeroginosa, Streptococcus aureus, Bacillus subtilis, Shigella smiled, and Candida albicans [25]. Likewise, in 1999 were evaluated the compounds 4',5,7-trihydroxy8-methyl-6-(3-methyl-[2-butenyl])-(2S)-flavanone (20), 4',5,7-trihydroxy-6-methyl-8-(3-methyl- [2-butenyl])(2S)-flavanone (21) and 4',5-dihydroxy-7-methoxy-6-(3-methyl-[2-butenyl])-(2S)-flavanone (22), from the aerial zone of Eysenhardtia texana Kunth from an extract of methanol and dichloromethane. The flavonones were active in inhibiting the growth of Staphylococcus aureus, and one of them also reduced the proliferation of Candida albicans [26,27]. 
Subsequently, the antimicrobial action of the methanol extracts of E. polystachya and E texana were studied to mitigate nine strains of bacteria and a yeast linked to urinary infections; the species evaluated were Escherichia coli, Proteus mirabilis, Proteus vulgaris, Klebsiella pneumoniae, Enterobacter aerogenes, Pseudomonas aeruginosa, Serratia marcescens, Staphylococcus aureus, Staphylococcus epidermidis, and Candida albicans. The results showed that E. texana had limited antibacterial activity; in contrast, E. polystachya showed a broad-spectrum antimicrobial effect against the microorganisms evaluated. The authors suggest its use as a possible alternative for the inhibition of Gram positive and Gram negative bacteria, since it exists there is a shortlist of appropriate drugs to inhibit these families of microorganisms [18].

In 2012, the antibacterial potential of 47 plants in oral infections was researched by analyzing ethanolic and aqueous extracts. E. polystachya, showed a reduction in the proliferation of Streptococcus mutans and Porphyromonas gingivalis [41].

Subsequently, the ethanol extract from the leaves and branches of E. polystachya was analyzed using the MTT test, as well as the lowest inhibitory concentration (MIC). The data showed activity for Escherichia coli (MIC $=1.56 \mu \mathrm{g} / \mathrm{mL}$ ), Staphylococcus aureus (MIC $=0.78 \mu \mathrm{g} / \mathrm{mL}$ ), and multi-resistant organisms (MIC $>100 \mu \mathrm{g} / \mathrm{mL}$ ) [12].

\subsection{Antidiabetic Activity}

Diabetes is a chronic degenerative disease related to hyperglycemia. Excess glucose in the blood causes health problems related to the generation of reactive oxidant species, the glycation of proteins, lipoperoxidation, difficulty in recognizing, sensitivity, and secretion of insulin, among others; this results in a diabetic pathology.

In 1998, the hypoglycemic capacity of 28 plants was evaluated; among the species analyzed was E. polystachya, which was considered an appropriate candidate to regulate glycemic levels in a pre-clinical study [11].

Subsequently, the antihyperglycemic activity of the methanolic extracts of the leaves (LEP), branches (BEP), and bark (REP) of Eysenhardtia platycarpa was studied in diabetic rats induced with streptozotocin, as well as in healthy animals. It was observed that the REP extract did not exhibit antihyperglycemic action compared to LEP and BEP. Additionally, the effect of 3-O-acetyloleanolic (72) acid (isolated from BEP) was observed in reducing blood glucose levels in diabetic rats.

In 2007, a study was published evaluating the antioxidant activity of the methanol extracts of $E$. platycarpa, E. puntacta, and E. subcoriacea in a murine pancreatic model. The tests showed that these species were protected from the damage induced by 2,2-azo-bis(2-amidinopropane)dihydrochloride (AAPH). Furthermore, some bioactives, (3-O-acetyl-11 $\alpha, 12 \alpha$-epoxy-oleanan-28,13 $\beta$-olide (69), $(+)$-catechin (33), and (+)-catechin-3-O- $\beta$-D-galactopyranoside (37)) isolated from the branches of E. platycarpa, showed radical scavenging capacity 2,2-diphenyl-1-picrylhydrazyl (DPPH), increase the concentration of pancreatic glutathione (GSH), the activity of glutathione peroxidase (GSHPx) and catalase (CAT), as well as regulating the gain in levels of glucose in diabetic rats induced with streptozotocin after five days of administration [33].

In 2008, the antioxidant activity of secondary metabolites identified in the aerial zone of E. subcoriacea was reported. Among the bioactive drugs described are 3-(2'-hydroxy-4', $5^{\prime}$-methylendioxyphenyl)6-(3"'-hydroxymethyl-4"'-hydroxybut-2'"-enyl)-7-hydroxycoumarin (32), (+)-catechin (33), (-)-epicatechin (34), (+)-afzelechin (35), eriodictyol (36), (+)-catechin 3-O- $\beta$-D-galactopyranoside (37), and quercetin 3-O- $\beta$-D-galactopyranoside (38), all of which countered the presence and development of free radicals (DPPH and AAPH) and can be used to suppress diabetic pathology [31].

In 2010, the antihyperglycemic and antioxidant effect of subcoriacin (3-aryl-6prenylcoumarin), a secondary metabolite from E subcoriacea, was researched. The administration of the bioactive compound to streptozotocin-induced diabetic rats for five days showed a reduction in blood glucose levels, increased activity of the enzymes (glutathione peroxidase (GSHPx), superoxide dismutase (SOD) 
and catalase (CAT)) of the endogenous system. For this reason, the protective action of Subcoriacin against pancreatic damage induced by free radicals under a diabetic condition [32] was suggested.

In 2014, the antioxidant, antidiabetic and antiglycation properties of the aqueous-methanolic extract of Eysenhardtia polystachya were analyzed. The ability to decrease and/or eliminate free radicals DPPH, ABTS, was noted, as well as the reactive oxygen species $\left(\mathrm{RO}_{2},-\mathrm{O}_{2}, \mathrm{H}_{2} \mathrm{O}_{2},-\mathrm{OH}, \mathrm{ONOO}-\right.$, $\mathrm{NO}-, \mathrm{HOCl}_{1}{ }^{1} \mathrm{O}_{2}$ ), and the ability to absorb oxygen radicals (ORAC) by donating electrons $\left(\mathrm{H}^{+}\right)$. The ability to sequester metals for the formation of chelates and decreased lipoperoxidation was also examined. At the same time, the activity to inhibit fluorescent AGEs, glycation of hemoglobin, and methylglyoxal products was determined. As for in vivo tests with strepzotocin-induced diabetic murine models, a decrease was observed in blood glucose levels, triglycerides (TG), total cholesterol (TC), thiobarbituric acid reactives substances (TBARS), and low-density lipoprotein (LDL). At the same time, an increase in serum insulin, body weight, and liver biomarkers were induced. Consequently, the methanolic-aqueous extract of EP demonstrated the ability to interact at the different points evaluated, exercising beneficial actions in the control of disorders associated with diabetes based on the presence of phenolic compounds [14].

In 2016, were analyzed six compounds $\left(2^{\prime}, 4^{\prime}\right.$-dihydroxychalcone- $6^{\prime}-O-\beta$-D-glucopyranoside (39), $\alpha, 3,2^{\prime}, 4^{\prime}$-tetrahydroxy-4-methoxy-dihydrochalcone-3'-C- $\beta$-glucopyranosi-6'-O- $\beta$-D-glucopyranoside (40), 7-hydroxy-5,8'-dimethoxy-6' $\alpha$-L-rhamnopyranosyl-8-(3-phenyl-transacryloyl)-1-benzopyran-2-one (41), 6'7-dihydroxy-5,8-dimethoxy-8(3-phenyl-trans-acryloyl)-1-benzopyran-2-one (42), 9-hydroxy-3,8dimethoxy-4-prenylterocarpan (43), and $\alpha, 4,4^{\prime}$-trihydroxy-dihydrochalcone-2'-O- $\beta$-D-glucopyranoside (45)) from the aqueous-methanol extract of the bark of Eysenhardtia polystachya, for their possible antioxidant potential, in streptozotocin-induced diabetic mice. The first five flavonoids showed favorable effects on the regulation and protection of hepatic and cellular biomarkers associated with disorders caused by oxidative stress in diabetes [34].

Furthermore, the inhibition capacity of 11 dihydrochalcones from the methanolic extract of the $E$. polystachya bark in the formation of advanced glycation end products (AGEs) was studied in their multiple stages (early, intermediate, and final). Protein glycation corresponds to the interaction of proteins with excess sugars in the body; this hyperglycemic condition occurs during diabetes. The tests carried out were in vitro, and it was concluded that each of the isolated bioactives were capable of inhibiting and protecting from the formation and accumulation of AGEs. The biocomposites analyzed were: ( 6 'methoxy-sieboldin (53), $2^{\prime}-O-\alpha$-L-rhamnopyranosyl- $\alpha, 6^{\prime}$, dihydroxy-4' acetyl-4-methoxy-dihydrochalcone (52), $2^{\prime}$-O- $\beta$-Dglucopyranosyl-4'-methoxy-4-hydroxy-3-isoprenyl-dihydrochalcone (54), $2^{\prime}, 4^{\prime}, 6^{\prime}$ trihydroxy-4,5dimethoxy-3-isoprenyl-dihydrochalcone (55), $3^{\prime}$-C- $\beta$-glucopyranosyl- $\alpha, 2^{\prime}, 4^{\prime}, 6^{\prime}$ - trihydroxy-4- methoxydihydrochalcone (56) and $3^{\prime}$-C- $\beta$-glucopyranosyl- $\alpha, 2^{\prime}, 4$-trihydroxy- $4^{\prime}, 6^{\prime}$-dimethoxy-dihydrochalcone) (57) the rest (3-hydroxyphloretin-4'-O- $\beta$-D-glucopyranoside (58), 3,4'-dihydroxy-2,4,6-trimethoxydihydrochalcone (59), 2', 4' 4 4-trihydroxy-3'-methoxy-dihydrochalcone (60), 2', $4^{\prime}, 6^{\prime}, 4$-tetrahydroxy-3, 5 -diisoprenyl-dihydrochalcone (61), and $\quad 3^{\prime}-C-\beta$-glucopyranosyl- $\alpha, 2^{\prime}, 4^{\prime}, 3,4$-penta-hydroxydihydroxychalcone (62)) had previously been elucidated [35].

In 2019, it was demonstrated that the bioactive $3^{\prime}$-O- $\beta$-D-glucopyranosyl $\alpha, 4,2^{\prime}, 4^{\prime}, 6^{\prime}$ pentahydroxy-dihydrochalcone (63) isolated from Eysenhardtia polystachya is an excellent antiglycation compound capable of reducing glycation of proteins responsible for diabetic nephropathy in diabetic individuals. Tests were carried out using diabetic mice with kidney problems induced with stretozotocin; levels of glycated hemoglobin $(\mathrm{HbA} 1 \mathrm{c})$, the concentration of glycation end products advances in the kidney and circulatory system, as well as in pro-inflammatory markers ICAM-1 were then analyzed. The bioactive (63) was administered for five weeks at different concentrations $(25,50$, and $100 \mathrm{mg} / \mathrm{kg})$; at the end of the dosing period the diabetic animals showed a significant improvement, suggesting the ability of the bioactive to react and inhibit early and intermediate precursors in the formation of AGEs, responsible for damaging the structure of the kidneys [36]. 


\subsection{Anti-Inflammatory Activity}

In 2015, the anti-inflammatory potential of the Eysenhardtia polystachya bark from hexane (PAH), chloroform (PAC), and methanol (PAM) extracts was researched. The extracts were evaluated using Wistar rats as an experimental model. To determine the anti-inflammatory activity of the extracts, different tests were used such as: carrageenan and croton oil induced edema. The tumor necrosis factor $\alpha(\mathrm{TNF}-\alpha)$, interleukin-1- $\beta$ (1L-1 $\beta)$, prostaglandin E2 (PGE2) and leukotriene B4 (LTB4) were also quantified. The PAM extract showed anti-inflammatory activity in the different induced edema inhibited the expression of the cytokines (TNF- $\alpha, 1 \mathrm{~L}-1 \beta$, PGE2 and LTB4), and the enzymes lipoxygenase and xanthine-oxidase linked to inflammatory problems [15].

Furthermore, in 2018 the properties of the ethanolic extract from the bark of E. polystachya to mitigate rheumatoid arthritis were analyzed. To do this, the antiarthritic activity induced by Complete Freund's Adjuvant (CFA) in rats was determined. Trials showed that secondary metabolites of E. polystachya, mainly flavonoids, inhibited secondary inflammatory processes in arthritic rats, encouraged histopathological changes, and reduced serum levels of inflammatory cytokines [16].

Additionally, in that same year, the anti-inflammatory effect of ethanol extract from the leaves and branches of E. polystachya was examined using in vitro tests stimulating macrophages using LPS. The results demonstrated a decrease in the production of $\mathrm{H}_{2} \mathrm{O}_{2}\left(\mathrm{IC}_{50}=43.9 \pm 3.8 \mu \mathrm{g} / \mathrm{mL}\right)$ and IL- 6 $(73.3 \pm 6.9 \mu \mathrm{g} / \mathrm{mL})[12]$.

\subsection{Antinociceptive Activity}

The importance of reducing or mitigating the sensation of pain has been fundamental for the control and treatment of different conditions, this has prompted the search for natural alternatives. In 2018, the ethanolic extract of the bark of E. polystachya was evaluated, using the acetic acid-induced abdominal contraction test and the hot-plate test, which were performed on mice. A decrease in the spasms generated by acetic acid and a prolonged sensitivity time at the peripheral and central levels [16] were observed.

Furthermore, in that same year, D-pinitol (80) isolated from ethanolic extract of Eysenhardia polystachya was examined to find out if it had the property to block or reduce pain. It was found that D-pinitol inhibited $67.58 \%$ with an effective dose of $10.7 \mathrm{mg} / \mathrm{kg}$; its activity is associated with the serotoninergic system (5-HT3) and nitric oxide [42].

Additionally, the antinociceptive effect of the ethanolic extract from leaves and branches of E. polystachya (EPE) was also studied, following the acetic acid, formalin, and hot plate test. It was identified that the extract contained $26.93 \%$ D-pinitol, the bioactive responsible for an action. EPE presented an effective dose of $117 \pm 14.5 \mathrm{mg} / \mathrm{kg}$ and $33 \pm 3.2 \mathrm{mg} / \mathrm{kg}$ for D-pinitol in acetic acid test; in the case of formalin it was $48.9 \pm 3.9 \mathrm{mg} / \mathrm{kg}$. The action of EPE is probably due to the involvement of ATP-sensitive $\mathrm{K}+$ channels. As for D-pinitol, its route of action is considered to occur at nitric oxide receptors and 5-hydroxytryptamine 3 (5-HT3) [12].

\subsection{Antidiarrheal}

The ability to stop diarrhea was analyzed from the ethanolic extract of the leaves and branches of E. polystachya (EPE) and the compound D-pinitol (80) isolated from E. polystachya. The results showed that the EPE extract had an effective dose of $7.5 \pm 0.9 \mu \mathrm{g} / \mathrm{mL}$ and the D-pinitol $0.1 \pm 0.03 \mu \mathrm{g} / \mathrm{mL}$. The results suggest that this was due to the elimination of intestinal fluid [12].

\subsection{Muscle Relaxant}

The pharmacological potential in Jejunum muscle contraction was explored using chloroform extract from the stems of E. polystachya in muscle tissue extracted from rabbits. The test showed that the extract presents an effect on jejunum contractility [43]. 


\subsection{Cytotoxic Activity}

In 1998, the cytotoxic activity of the bioactives ((3S) -7-hydroxy- $2^{\prime}, 3^{\prime}, 4^{\prime}, 5^{\prime}, 8$-pentamethoxyisoflavan (10), (3S)-3', 7-dihydroxy-2', $4^{\prime}, 5^{\prime}, 8$-tetramethoxyisoflavan (11), isoduartine (2',7-dihydroxy-3' $4^{\prime}, 8-$ trimethoxyisoflavan)(14)) was evaluated; these were isolated from the chloroform-methanol extract of the bark of E. polystachya. The identified metabolites showed slight cytotoxic activity against the cell lines (KB (nasopharyngeal carcinoma), P388 (murine leukemia) and SQC-1 UISO (squamous cell carcinoma of the cervix)) [8].

\subsection{Nanoparticles and Eysenhardtia}

Furthermore, in 2018 silver nanoparticles were synthesized with the aqueous methanol extract of Eysendhartia polystachya and their performance in inhibiting AGEs in vitro tests cell viability with RAW-264.7 cells was analyzed and in vivo tests with diabetic zebrafish induced by glucose exposure were performed. It was found that the bioactives present in the nanostructures can counteract protein glycosylation through their intervention in the neutralization and elimination of fluorescent, non-fluorescent, free radical AGEs, and the catchment of methylglyoxal together with its derivatives. Regarding diabetic fish, these showed a decrease in the conditions caused by chronic hyperglycemia. Their results suggest the use of nanoparticles for diabetic pathology [44].

Also, in 2018, silver nanoparticles biosynthesized with the aqueous methanolic extract from the bark of E. polystachya were used as delivery and transport systems for polyphenolic constituents. The cell viability (murine RAW-264.7 macrophage cells) and biocompatibility of nanostructures was determined, as well as the E. polystachya extract. The antioxidant effect of the synthesized nanometric material on the biomarkers of zebrafish embryos exposed to a medium with high glucose concentrations was also studied. Treatments using nanoparticles and plant extracts increased the activity of the antioxidant enzymes (SOD, CAT, and GPx) and reduced the damage caused by the formation of reactive oxidative species, positively influencing the total protein concentration while decreasing the formation of malondialdehyde (MDA) and lipoperoxidation. Consequently, nanostructures with a high content of phenolic compounds could be a viable alternative in minimizing the diabetic complications associated with oxidative stress [45].

In that same year, the antidiabetic properties (qualities) of the bio-nanofabricated silver nanoparticles were evaluated using the hydroalcoholic extract of Eysenhardtia polystachya (EP/AgNPs). They demonstrated the protective action of EP/AgNPs against damage caused by hydrogen peroxide to INS-I cells, minimizing cell mortality, also having a cytoprotective action against oxidative laceration. Furthermore, it was observed that when administering the EP/AgNPs to glucose-induced diabetic zebrafish $(111 \mathrm{mM})$, they showed an improvement in the levels of blood glucose, insulin, triglycerides, and cholesterol; helping to regulate hyperglycemic, hyperlipidemic, and insulin sensitivity. The authors suggest the possibility of using E. polystachya nanostructures as an alternative therapy for the control of diabetes due to their high concentration of chalcones, dihydrochalcones, and flavonoids [46].

Furthermore, nanoparticles have been synthesized and functionalized with the extract of E. polystachya using biological applications by taking advantage of the composition of the plant's fluorescent biocomposites; these can then be used as a fluorescent cell nanomarker to detect cancer or pathogenic microorganisms [47].

\subsection{Other Applications}

The bioactive molecules responsible for the fluorescence of E. polystachya were isolated and elucidated from the methanol extract of the heartwood. Among the bioactives isolated are; 7-hydroxy-2', 4', 5' -trimethoxyisoflavone (16) and 9-methoxy-2,3-methylenedioxycoumestan (47) corresponding to Robert Boyle's acid-base fluorescent indicator used in the 17th century [24]. 
Also, the activity of the extracts of ethyl acetate, dichloromethane, hexane, and methanol was determined from calluses and suspended cells of E. polystachya for the control of fungal phytopathogens. The information obtained provided an opportunity to propose plant extracts as a fungicide option [48].

Nine fractions of the E. polystachya ethanolic extract were also evaluated for use as fluorescent biosensors. Six of the nine fractions tested positive for photoluminescence and only two were stable for use in the functionalization of silica nanoparticles. The G2 subfraction demonstrated appropriate fluorescence qualities at a physiological $\mathrm{pH}$ and its detection also did not show toxicity, allowing cell viability [49].

\section{Conclusions}

Currently, there are many diseases linked to factors related to metabolic syndrome. This condition has caused people to develop various health problems and increases their risk of mortality. This has caused a large part of society to live under a constant medication scheme that attempts to regulate the ailments that afflict them, which in turn stimulates the consumption of natural alternatives that have shown to help control symptoms. In this paper, we present the potential of the extracts and/or bioactives of the Eysenhardtia genus to limit the proliferation of microbial infections, urinary disorders, oxidative stress, protein glycation, lipoperoxidation, increase in blood sugar levels, inflammation, or the development of bodily discomfort. Furthermore, the introspection performed made it clear that the composition of phytochemical compounds and their diversity of secondary metabolites could be a complementary solution for individuals affected by comorbidity.

Author Contributions: Writing—original draft preparation, A.G.-C. and A.M.-R.; writing-review and editing, E.G. and A.M.-R. All authors have read and agreed to the published version of the manuscript.

Funding: Consejo Nacional de Ciencia y Tecnología (CONACYT), project FORDECYT-CIIDZA: 296354.

Acknowledgments: We acknowledge the funding from CONACYT (FORDECYT-CIIDZA: 296354). The authors thank Biologist Juan Pablo Brunei, for providing the images of the plant for publication.

Conflicts of Interest: The authors declare no conflict of interest.

\section{References}

1. Petrovska, B. Historical review of medicinal plants' usage. Pharmacogn. Rev. 2012, 6, 1-5. [CrossRef] [PubMed]

2. Jamshidi-Kia, F.; Lorigooini, Z.; Amini-Khoei, H. Medicinal plants: Past history and future perspective. J. Herbmed. Pharmacol. 2018, 7, 1-7. [CrossRef]

3. Dar, R.A.; Shahnawaz, M.; Qazi, P.H. General overview of medicinal plants: A review. J. Phytopharm. 2017, 6, 349-351.

4. Heinrich, M.; Ankli, A.; Frei, B.; Weimann, C.; Sticher, O. Medicinal Plants in Mexico: Healers' Consensus and Cultural Importance. Soc. Sci. Med. 1998, 47, 1859-1871. [CrossRef]

5. Esquivel, R.G.; Pérez, E.C.; Ochoa, A.Z.; García, M.E.P. Ethnomedicinal plants used for the treatment of dermatological affections on the Purépecha Plateau, Michoacán, Mexico. Acta Bot. Mex. 2018, 125, 95-132. [CrossRef]

6. Monardes, N.B. Historia Medicinal de las Cosas que se Traen de Nuestras Indias Occidentales que Sirven en Medicina; Padilla Libros: Sevilla, Spain, 1565; pp. 1-276.

7. Acuña, A.U.; Amat-Guerri, F. Early History of Solution Fluorescence: The Lignum nephriticum of Nicolás Monardes. Springer Ser. Fluoresc. 2008, 4, 3-20.

8. Alvarez, L.; Rios, M.Y.; Esquivel, C.; Chavez, M.I.; Delgado, G.; Aguilar, M.I.; Villarreal, M.L.; Navarro, V. Cytotoxic isoflavans from Eysenhardtia polystachya. J. Nat. Prod. 1998, 61, 767-770. [CrossRef]

9. Muyskens, M.; Vitz, E. The Fluorescence of Lignum nephriticum: A Flash Back to the Past and a Simple Demonstration of Natural Substance Fluorescence. J. Chem. Educ. 2009, 83, 765-768. [CrossRef]

10. Torres, P.A.A.; Lomeli, M.G.R.; Lopez, F.D.; Fuentes, F.J.T.; Richter, H.G.; Silva, J.A.G. Natural decay resistance of Eysenhardtia polystachya (Ortega) Sarg. Int. Wood Prod. J. 2010, 1, 81-84. 
11. Alarcon-Aguilar, F.J.; Roman-Ramos, R.; Pérez-Gutierrez, S.; Aguilar-Contreras, A.; Contreras-Weber, C.C.; Flores-Saenz, J.L. Study of the anti-hyperglycemic effect of plants used as antidiabetics. J. Ethnopharmacol. 1998, 61, 101-110. [CrossRef]

12. Alonso-Castro, A.J.; Zapata-Morales, J.R.; Arana-Argáez, V.; Torres-Romero, J.C.; Ramirez-Villanueva, E.; Pérez-Medina, S.E.; Ramirez-Morales, M.A.; Juarez-Mendez, M.A.; Infante-Barrios, Y.P.; Marinez-Gutierrez, F.; et al. Pharmacological and toxicological study of a chemical-standardized ethanol extract of the branches and leaves from Eysenhardtia polystachya (Ortega) Sarg. (Fabaceae). J. Ethnopharmacol. 2018, 224, 314-322. [CrossRef] [PubMed]

13. Beltrami, E.; De Bernardi, M.; Fronza, G. Coatline A and B, two C-Glucosyl- $\alpha$-hydroxydihydrochalcones from Eysenhardtia polystachya. Phytochemistry 1982, 21, 2931-2933. [CrossRef]

14. Pérez-Gutierrez, R.; Garcia-Baez, E. Evaluation of antidiabetic, antioxidant and antiglycating activities of the Eysenhardtia polystachya. Pharmacogn. Mag. 2014, 10, 404-418. [CrossRef] [PubMed]

15. Pérez-Gutierrez, R.M. Evaluation of anti-inflammatory activity of the bark of Eysenhardtia polystachya in experimental animal models. Afr. J. Pharm. Pharmacol. 2015, 9, 230-236.

16. Pablo-Pérez, S.S.; Parada-Cruz, B.; Barbier, O.C.; Meléndez-Camargo, M.E. The ethanolic extract of Eysenhardtia polystachya (Ort.) Sarg. Bark and its fractions delay the progression of rheumatoid arthritis and show antinociceptive activity in murine models. Iran J. Pharm. Res. 2018, 17, 236-248. [PubMed]

17. Camacho-Morfin, F. Germinación de semillas de palo dulce (Eysenhardtia polystachya). Rev. Cienc. For. 1987, 62, 3-13.

18. Rivas-Morales, C.; Oranday-Cardenas, M.A.; Verde-Star, M.J.; Morales-Rubio, M.E.; Garza-González, E. Activity of extracts from two Eysenhardtia species against microorganisms related to urinary tract infections. Br. J. Biomed. Sci. 2009, 66, 102-106. [CrossRef]

19. Sarg, O. Eysenhardtia polystachya. Silva N. Am. 1892, 3, 1-4. Available online: http://www.conabio.gob.mx/ conocimiento/info_especies/arboles/doctos/28-legum18m.pdf (accessed on 13 July 2020).

20. CONAFOR. Fichas técnicas sobre características tecnológicas y usos de maderas comercializadas en México. Tomo II. SEMARNAT 2007, 1, 83-84.

21. Lang, J.M. Eysenhardtia (Leguminosae): Taxonomic Revision and Relationships. Ph.D. Thesis, Iowa State University, Ames, IA, USA, 1972. Available online: https://ib.dr.iastate.edu/rtd/4750 (accessed on 13 July 2020).

22. Gutierrez, L.; Sumano, H.; Rivero, F.; Alcala, Y. Ixodicide activity of Eysenhardtia polystachya against Rhipicephalus (Boophilus) microplus. J. Anim. Sci. 2015, 93, 1980-1986. [CrossRef]

23. Contu, S. Eysenhardtia polystachya. IUCN Red List Threat. Species 2012, 1. [CrossRef]

24. Burns, D.T.; Dalgarno, B.G.; Gargan, P.E.; Grimshaw, J. An isoflavone and a coumestan from Eysenhardtia polystachya-Robert Boyle's fluorescent acid-base indicator. Phytochemistry 1984, 23, 167-169. [CrossRef]

25. Alvarez, L.; Delgado, G. C-and O-glycosyl- $\alpha$-hydroxydihydrochalcones from Eysenhardtia polystachya. Phytochemistry 1999, 50, 681-687. [CrossRef]

26. Hoffmann, J.J.; Wachter, G.A.; Gutterman, J.U. Antibacterial and Antifungal Flavonones from Eysenhardtia texana. U.S. Patent 6,136,849, 24 October 2000.

27. Wächter, G.A.; Hoffmann, J.J.; Furbacher, T.; Blake, M.E.; Timmermanm, B.N. Antibacterial and antifungal flavanones from Eysenhardtia texana. Phytochemistry 1999, 52, 1469-1471. [CrossRef]

28. Pérez, R.M.G.; Vargas, S.R.; Perez, G.S.; Zavala, M.S.; Perez, C.G. Antiurolithiatic activity of 7-hydroxy-2' $4^{\prime}, 5^{\prime}$-trimethoxyisoflavone and 7-hydroxy-4'- methoxyisoflavone from Eysenhardtia polystachya. J. Herbs. Spices Med. Plants 2000, 7, 27-34. [CrossRef]

29. Pérez, R.M.G.; Vargas, R.S.; García, L.M.D.; Dávila, L.B. Efecto de isoflavonas aisladas de la corteza de Eysenhardtia polystachya sobre el crecimiento de cristales de oxalato y fosfato de calcio urinario. Bol. Col. Mex. Urol. 2002, 17, 134-139.

30. Narváez-Mastache, J.M.; Garduño-Ramírez, M.L.; Alvarez, L.; Delgado, G. Antihyperglycemic activity and chemical constituents of Eysenhardtia platycarpa. J. Nat. Prod. 2006, 69, 1687-1691. [CrossRef]

31. Narváez, J.M.; Soto, C.; Delgado, G. Antioxidant evaluation of Eysenhardtia species (Fabaceae): Relay synthesis of 3-O-Acetyl-11 $\alpha, 12 \alpha$-epoxy-oleanan-28,13 $\beta$-olide isolated from E. platycarpa and its protective effect in experimental diabetes. Biol. Pharm. Bull. 2007, 30, 1503-1510. [CrossRef]

32. Narvaez, J.; Novillo, F.; Delgado, G. Antioxidant aryl-prenylcoumarin, flavan-3-ols and flavonoids from Eysenhardtia subcoriacea. Phytochemistry 2008, 69, 451-456. [CrossRef] 
33. Narváez, J.M.; Soto, C.; Delgado, G. Hypoglycemic and antioxidant effects of Subcoriacin in normal and streptozotocin-induced diabetic rats. J. Mex. Chem. Soc. 2010, 54, 240-244.

34. Pérez, R.M.G.; Garcia, A.H.C.; Muñiz, A.R. Properties of Flavonoids Isolated from the Bark of Eysenhardtia polystachya and their effect on oxidative stress in streptozotocin-induced diabetes mellitus in mice. Oxid. Med. Cell. Longev. 2016, 2016. [CrossRef]

35. Pérez, R.M.G.; Garcia, A.H.C.; Mota, J.M.F. Dihydrochalcones from the Bark of Eysenhardtia polystachya inhibits formation of advanced glycation end products at multiple stages in vitro studies. J. Pharm. Pharmacol. 2017, 1, 3-23.

36. Pérez, R.M.G.; García, A.H.C.; Paredes, S.P.C.; Muñiz, A.R.; Mota, J.M.F.; Flores-Valle, S.O. $3^{\prime}$-O- $\beta$-d-glucopyranosyl- $\alpha, 4,2^{\prime}, 4^{\prime}, 6^{\prime}$-pentahydroxy-dihydrochalcone, from bark of Eysenhardtia polystachya prevents diabetic nephropathy via inhibiting protein glycation in STZ-nicotinamide induced diabetic mice. Molecules 2019, 24, 1214. [CrossRef] [PubMed]

37. Pérez, R.M.G.; Vargas, R.S.; Perez, S.G.; Zavala, M.S. Antiurolithiatic activity of Eysenhardtia polystachya aqueous extract on rats. Phyther. Res. 1998, 12, 144-145. [CrossRef]

38. Pablo, S.S.P.; Estévez, M.M.C.; Meléndez, M.E.C. Diuretic activity of the bark of Eysenhardtia polystachya. Bangladesh J. Pharmacol. 2016, 11, 212-217. [CrossRef]

39. Aggarwal, A.; Singla, S.K.; Tandon, C. Urolithiasis: Phytotherapy as an adjunct therapy. Indian J. Exp. Biol. 2014, 53, 103-111.

40. Zavala, M.A.S.; Perez, S.G.; Perez, R.M.G. Antimicrobial screening of some medicinal plants. Phyther. Res. 1997, 11, 368-371. [CrossRef]

41. Rosas-Piñon, Y.; Mejia, A.; Diaz-Ruiz, G.; Aguilar, M.I.; Sanchez-Nieto, S.; Rivero-Cruz, J.F. Ethnobotanical survey and antibacterial activity of plants used in the Altiplane region of Mexico for the treatment of oral cavity infections. J. Ethnopharmacol. 2012, 141, 860-865. [CrossRef]

42. Pérez-Medina, S.E.; Alonso-Castro, A.J. Determinación del efecto analgésico de D-pinitol, un compuesto obtenido de Eysenhardtia polystachya (Ortega) Sarg. (Fabaceae). Jovenes Ciencia. Rev. Divulg. Cient. 2018, 4, 1197-1201.

43. Cortés-Arroyo, A.R.; Lara-Chacón, B.; Aoki-Maki, K. Screening and selection of plants by positive pharmacologic effect on jejunum muscular contractility. Pharm. Biol. 2004, 42, 24-29. [CrossRef]

44. Pérez, R.M.G.; Martinez, F.F.J.; Garcia, A.H.C.; Hoyo, C.V. Silver nanoparticles synthesized using Eysenhardtia polystachya and assessment of the inhibition of glycation in multiple stages in vitro and in the Zebrafish Model. J. Clust. Sci. 2018, 29, 1291-1303.

45. Garcia, A.H.C.; Martinez, F.F.J.; Perez, R.M.G.; Muñiz, A.R. Silver nanoparticles synthesized with a fraction from the bark of Eysenhardtia polystachya with high chalcone and dihydrochalcone content effectively inhibit oxidative stress in the zebrafish embryo model. Nanomed. J. 2018, 5, 152-162.

46. Garcia, A.H.C.; Perez, R.M.G.; Manriquez, G.A.; Muñiz, A.R. Protection of silver nanoparticles using Eysenhardtia polystachya in peroxide-induced pancreatic $\beta$-cell damage and their antidiabetic properties in zebrafish. Int. J. Nanomed. 2018, 13, 2601-2612. [CrossRef] [PubMed]

47. Ferreira, G.; Hernandez-Martinez, A.R.; Pool, H.; Molina, G.; Cruz-Sosa, M.; Luna-Barcenas, G.; Estevez, M. Synthesis and functionalization of silica-based nanoparticles with fluorescent biocompounds extracted from Eysenhardtia polystachya for biological applications. Mater. Sci. Eng. C 2015, 57, 49-57. [CrossRef]

48. Bernabé-Antonio, A.; Maldonado-Magaña, A.; Ramírez-López, C.B.; Salcedo-Lopez, E.; Meza-Contreras, J.C.; Gonzalez-Garcia, Y.; Lopez-Dellamary, F.A.T.; Cruz-Sosa, F. Establishment of callus and cell suspension cultures of Eysenhardtia polystachya (Ortega) and fungistatic activity of their extracts. S. Afr. J. Bot. 2017, 112, 40-47. [CrossRef]

49. Hernandez-Martinez, Á.R.; Molina, G.A.; Rodríguez-Torres, A.; Ledesma-Mendoza, B.; Del-Real, A.; Barroso-Flores, J.; Estevez, M. Fluorescence decay rate of selected compounds from Eysenhardtia polystachya extracts and their viability as biosensors. Mater. Sci. Eng. C 2019, 104, 109978. [CrossRef]

(C) 2020 by the authors. Licensee MDPI, Basel, Switzerland. This article is an open access article distributed under the terms and conditions of the Creative Commons Attribution (CC BY) license (http://creativecommons.org/licenses/by/4.0/). 